\title{
Water dynamics under changing land cover
}

\author{
J. Vaze, Y. Q. Zhang, and L. Zhang \\ CSIRO Land and Water Flagship, GP.O. Box 1666, Canberra, ACT 2601, Australia \\ Correspondence to: J. Vaze (jai.vaze@csiro.au)
}

Received: 12 March 2015 - Accepted: 12 March 2015 - Published: 12 June 2015

\begin{abstract}
Most of the forested headwater catchments are an important source of water supply in many parts of the world. A prime example is southeast Australia where forests supply major river systems and towns and cities with water. It is critical for an informed and adaptive water resource management to understand changes in streamflow caused by vegetation changes in these headwater forest catchments. Natural disturbances such as bushfires and anthropogenic activities like forestation, deforestation, or logging alter vegetation, evapotranspiration and soil water status, and may affect water supplies. Although catchment water yield is mainly controlled by climatic conditions, but it is also strongly influenced by land cover changes because of natural disturbances and anthropogenic activities. It is necessary to accurately estimate streamflow in water supply catchments subjected to dramatic land surface changes. This paper summarises the methods commonly used to investigate the impacts of land cover change on water resources, and provides some examples of impacts of afforestation/deforestation and bushfire on water resources in two southeast Australian catchments.
\end{abstract}

\section{Introduction}

There are numerous studies reported in literature which investigate the impacts of land use/land cover change and climate variability on catchment water availability (Vertessy, 1999; Vaze et al., 2004; Zhao et al., 2010; Nangia et al., 2010) and there is sufficient evidence that afforestation can reduce streamflow substantially (Zhang et al., 2001; Jackson et al., 2005; Lane et al., 2005). The total water use of plantations depends on the climatic factors affecting water demand, the amount and seasonal distribution of rainfall, the hydrological factors affecting supply and the response of trees to climate, hydrology and plantation management. As water use by forest changes as the forest ages, the streamflow in forested catchments is also affected by the ageing of the forest. Typically, streamflow increases immediately following the destruction of mature forest due to the reduction in interception and water use. The streamflow then decreases as the forest regrows and increases water use. This decrease in streamflow and the temporal span varies depending on whether the forest regrows to achieve a "full recovery" or a "partial recovery".

There is normally an increase in streamflow immediately following deforestation/clearing and this increase varies depending on the forest type and climate zone (Fig. 1a). The decrease in streamflow during the regrowth period follow- ing deforestation/bushfire is also dependent on the forest type and climate zone but the variability is much higher in the case of bushfire as there can be either a "full recovery" or only a "partial recovery" and it is also a function of the severity of the disturbance and area burnt (Fig. 1b). In case of a full recovery after bushfire, we expect the streamflow to decrease to be pretty much same as that of the pre-bushfire period but the recovery time is dependent on the forest type and postbushfire climatic conditions.

\section{Methods}

The most commonly used methods for estimating impacts of plantations on water availability are catchment experiment method and statistical analysis method and to a lesser extent the hydrological modelling method. The catchment experiment method is traditionally used for estimating the effect of forest management practices, such as afforestation and deforestation on catchment water availability (Hewlett et al., 1969). A number of catchment afforestation and deforestation studies have been conducted since 1960s (Hewlett et al., 1969; Van Lill et al., 1980; Lane et al., 2005; Tuteja et al., 2007). Most of the results indicate that catchment runoff is 


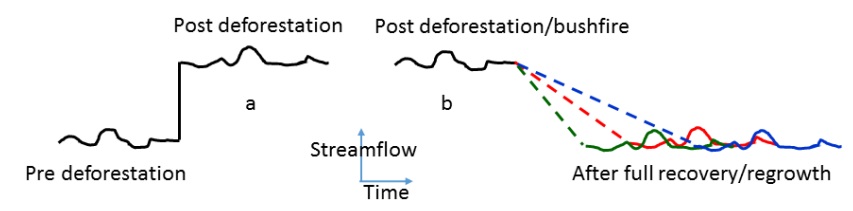

Figure 1. Increase/decrease in streamflow due to (a) deforestation/clearing and (b) afforestation/bushfire recovery.

significantly decreased after afforestation and obviously increase after deforestation.

For a given catchment that is not subjected to regulation or diversion, the total change in mean annual streamflow between two independent periods with different land cover and climate characteristics can be estimated as

$\Delta Q_{\mathrm{tot}}=\overline{Q_{\mathrm{obs}}^{1}}-\overline{Q_{\mathrm{obs}}^{2}}$

where $\Delta Q_{\text {tot }}$ indicates the total change in mean annual streamflow, $\overline{Q_{\mathrm{obs}}^{1}}$ and $\overline{Q_{\mathrm{obs}}^{2}}$ are the mean annual measured streamflow during the first period and the second period, respectively.

The total change $\Delta Q_{\text {tot }}$ in mean annual streamflow between the two independent periods is a combination of change in streamflow caused by the climatic differences between the two periods and change in streamflow due to the difference in catchment characteristics between the two periods. So, the total change in mean annual streamflow can be described as

$\Delta Q_{\mathrm{tot}}=\Delta Q_{\mathrm{cc}}+\Delta Q_{\mathrm{clim}}$

where $\Delta Q_{\mathrm{cc}}$ indicates the change in mean annual streamflow as a result of change in catchment characteristics between the two periods, $\Delta Q_{\text {clim }}$ is the change in mean annual streamflow because of climate change/climate variability between the two periods. In the catchments where there are no major regulations or diversions, changes in catchment characteristics are mainly caused by changes in vegetation. Therefore, $\Delta Q_{\mathrm{cc}}$ is approximately regarded as $\Delta Q_{\mathrm{lc}}$, change in mean annual streamflow caused by change in vegetation.

To separate streamflow impacts caused by climate change and vegetation change, only $\Delta Q_{\text {clim }}$ or $\Delta Q_{\text {lc }}$ needs to be quantified since $\Delta Q_{\text {tot }}$ is available. A widely used approach to quantify $\Delta Q_{\text {clim }}$ is the sensitivity-based approach (Koster and Suarez, 1999; Milly and Dunne, 2002; Sankarasubramanian et al., 2001). In this approach, $\Delta Q_{\text {clim }}$ is estimated from changes in mean annual precipitation $(\Delta P)$ and mean annual APET and their sensitivity coefficients. Another approach used to quantify $\Delta Q_{\text {clim }}$ is the hydrological modelling approach (Bultot et al., 1990; Nandakumar and Mein, 1997; Elfert and Bormann, 2010; Li et al., 2012). In this approach, hydrological models are first calibrated for one period, and then are applied to another independent period to quantify $\Delta Q_{\text {clim }}$. The following two sections provide more details about these two approaches.

\subsection{The Sensitivity-based approach}

As described above, $\Delta Q_{\text {clim }}$ is estimated from $\Delta P$ and $\triangle \mathrm{APET}$ using the following expression

$\Delta Q_{\text {clim }}=f_{P}^{\prime} \Delta P+f_{\mathrm{APET}}^{\prime} \Delta_{\mathrm{APET}}$

where $f_{P}^{\prime}$ is the sensitivity coefficient to mean annual precipitation and $f_{\mathrm{APET}}^{\prime}$ is the sensitivity coefficient to mean annual APET. According to Zheng el al. (2009), Eq. (3) is re-written as

$$
\begin{aligned}
& \Delta Q_{\mathrm{clim}}=\left(\varepsilon_{P} \Delta P / \bar{P}+\varepsilon_{\mathrm{APET}} \Delta \mathrm{APET} / \overline{\mathrm{APET}}\right) \bar{Q}, \\
& \quad \text { and } \varepsilon_{P}+\varepsilon_{\mathrm{APET}}=1
\end{aligned}
$$

where $\varepsilon_{P}$ and $\varepsilon_{\text {APET }}$ are elasticity of streamflow with respect to $P$ and APET. Overbars indicate averages over a longterm period (including both periods). To estimate $\Delta Q_{\text {clim }}$ using Eq. (4), one needs to estimate precipitation elasticity of streamflow $\left(\varepsilon_{P}\right)$. The two widely used methods for estimating $\varepsilon_{P}$ are described below.

\subsection{Non-parametric estimator of $\varepsilon_{P}$}

Sankarasubramanian et al. (2001) developed a nonparametric method to estimate $\varepsilon_{P}$ as follow

$\varepsilon_{P}=\operatorname{median}\left(\frac{\left(Q_{i}-\bar{Q}\right) / \bar{Q}}{\left(P_{i}-\bar{P}\right) / \bar{P}}\right)$

where $Q_{i}$ and $P_{i}$ are annual $P$ and annual $Q$ for the $i$ th year.

\subsection{Budyko-framework estimator of $\varepsilon_{P}$}

In unregulated catchments where the average change in catchment water storage is negligible compared to the cumulative precipitation, evapotranspiration and runoff in a long period of over 5 years (Hobbins et al., 2001; Teng et al., 2012), catchment mean annual runoff can be estimated as

$\bar{Q}=\bar{P}-\bar{E}$

where $\bar{E}$ is catchment mean annual evapotranspiration. In the traditional Budyko-framework (Budyko, 1958), $\bar{E}$ is taken as a function of aridity index $(\mathrm{AI}=\overline{\mathrm{APET}} / \bar{P})$

$\bar{E}=\bar{P} f(\mathrm{AI})$

An analytical solution is derived to estimated $\varepsilon_{P}$ according to the Budyko-framework (Dooge et al., 1999; Kuhnel et al., 1991) as follow

$\varepsilon_{P}=1+\frac{\mathrm{AI} f^{\prime}(\mathrm{AI})}{1-f^{\prime}(\mathrm{AI})}$

According to the Eq. (8), $\varepsilon_{P}$ can be estimated for a given $\mathrm{AI}$, once the form of $f(\mathrm{AI})$ is given. Table 1 shows six commonly used forms of $f(\mathrm{AI})$ and $f^{\prime}(\mathrm{AI})$, based on the Budyko-framework. 
Table 1. The six commonly used forms of expressions and their first derivatives based on the Budyko framework.

\begin{tabular}{|c|c|c|}
\hline Expression form & $f(\mathrm{AI})$ & $f^{\prime}(\mathrm{AI})$ \\
\hline Schreiber (1904) & $1-e^{-\mathrm{AI}}$ & $e^{-\mathrm{AI}}$ \\
\hline Ol'dekop (1911) & $\operatorname{AItanh}(1 / \mathrm{AI})$ & $\tanh (1 / \mathrm{AI})-4 /\left[\mathrm{AI}\left(e^{-1 / \mathrm{AI}}+e^{1 / \mathrm{AI}}\right)^{2}\right]$ \\
\hline Budyko (1958) & $\mathrm{AI} \tanh (1 / \mathrm{AI})\left(1-e^{-\mathrm{AI}}\right)^{0.5}$ & $\begin{array}{l}0.5\left[\mathrm{AI} \tanh (1 / \mathrm{AI})\left(1-e^{-\mathrm{AI}}\right)\right]^{-0.5} \\
{\left[\left(\tanh (1 / \mathrm{AI})-1 / \mathrm{AI} \sec h^{2}(1 / \mathrm{AI})\right)\left(1-e^{-\mathrm{AI}}\right)\right.} \\
\left.+\mathrm{AI} \tanh (1 / \mathrm{AI}) e^{-\mathrm{AI}}\right]\end{array}$ \\
\hline Turc-Pike (1964) & $1 / \sqrt{1+\mathrm{AI}^{-2}}$ & $1 /\left[\mathrm{AI}^{3}\left(1+(1 / \mathrm{AI})^{2}\right)^{1.5}\right]$ \\
\hline $\mathrm{Fu}(1981)$ & $1+\mathrm{AI}-\left(1+\mathrm{AI}^{\alpha}\right)^{1 / \alpha}, \alpha=2.5$ & $1-\left(1+\mathrm{AI}^{2.5}\right)^{-0.6} \mathrm{AI}^{1.5}$ \\
\hline Zhang (2001) & $(1+w \mathrm{AI}) /(1+w \mathrm{AI}+1 / \mathrm{AI}), w=1$ & $\left(2 / \mathrm{AI}+1 / \mathrm{AI}^{2}\right) /(1+\mathrm{AI}+1 / \mathrm{AI})^{2}$ \\
\hline
\end{tabular}

\subsection{Dynamic hydrological modelling approach}

Hydrological modelling is an effective approach to simulate surface hydrological processes and to understand and interpret catchment hydrological behaviours. Among variety of hydrological models, conceptual rainfall-runoff models are widely used for surface runoff prediction due to their simple structure and few parameters (Zhang and Chiew, 2009; Vaze et al., 2011; Lerat et al., 2012; Zhou et al., 2013, 2014). For the application in afforestation/deforestation studies, the hydrological model is first calibrated and validated within the afforestation and/or deforestation periods separately to make sure that both the calibration and validation periods have a relatively similar vegetation cover. About half to two-third of the observed streamflow data is normally used to calibrate the model and the calibrated parameter values are used to simulate streamflow for the remaining one-third period. The observed and simulated streamflow over the non-calibration period is compared to determine the suitability of the model for afforestation/deforestation studies. The model is considered suitable for use in afforestation/deforestation study if the calibration/validation bias is low and the model is able to reproduce the observed streamflow in the validation period.

Once the model is successfully calibrated, it is used to quantify the relative effects of plantation expansion or reduction and climate variability/change on streamflow. In case of afforestation/deforestation, the entire pre-afforestation/predeforestation period is used for model calibration. The calibrated parameter values are then used to simulate streamflow for the afforested/deforested period. The observed and simulated streamflow over the afforested/deforested period is then used to quantify the change in runoff due to plantation differences (afforestation/deforestation) and climate variability between the pre-afforestation and afforested or pre-deforestation and deforestation periods.

\section{Case studies}

We present the results from two case studies conducted for catchments in southeast Australia. The first case study evaluates afforestation impacts on water yield and the second study is carried out to evaluate deforestation/bushfire impacts.

\subsection{Afforestation case study}

The Crawford River catchment is about $700 \mathrm{~km}^{2}$ and located in Victoria, Australia. The climate is temperate, with cool and wet winters and mild to warm and dry summers. Mean annual rainfall is $762 \mathrm{~mm}$ (pre-afforestation $775 \mathrm{~mm}$ and after afforestation $736 \mathrm{~mm}$ ) and mean annual areal potential evapotranspiration (APET) is $1091 \mathrm{~mm}$ (pre-afforestation $1087 \mathrm{~mm}$ and after afforestation $1106 \mathrm{~mm}$ ). Before 1998, the Crawford River catchment was mostly under grazing on sown or modified pastures with very small coverage of hardwood (Eucalyptus globulus) and softwood (Radiata pine, Pinus radiata) plantations. Tasmanian blue gum plantations (E. globulus) were introduced gradually in around $25 \%$ of the catchment starting from 1998 until 2005 to replace the existing pasture.

This study investigated the impacts of plantation expansion and climate variability on streamflow in the Crawford River catchment using observed data and above described nine different methods (one non-parametric method, six Budyko framework based methods and two conceptual hydrological models (SIMHYD and Xinanjiang)). The box and whiskers plots in Fig. 2a show the percentage reduction in streamflow during the afforested period due to increase in plantations and drier climate estimated by the nine approaches. The reductions in streamflow due to increase in plantations when using the nine approaches range between 32 and $42 \%$ with a median of $40 \%$. The corresponding re- 


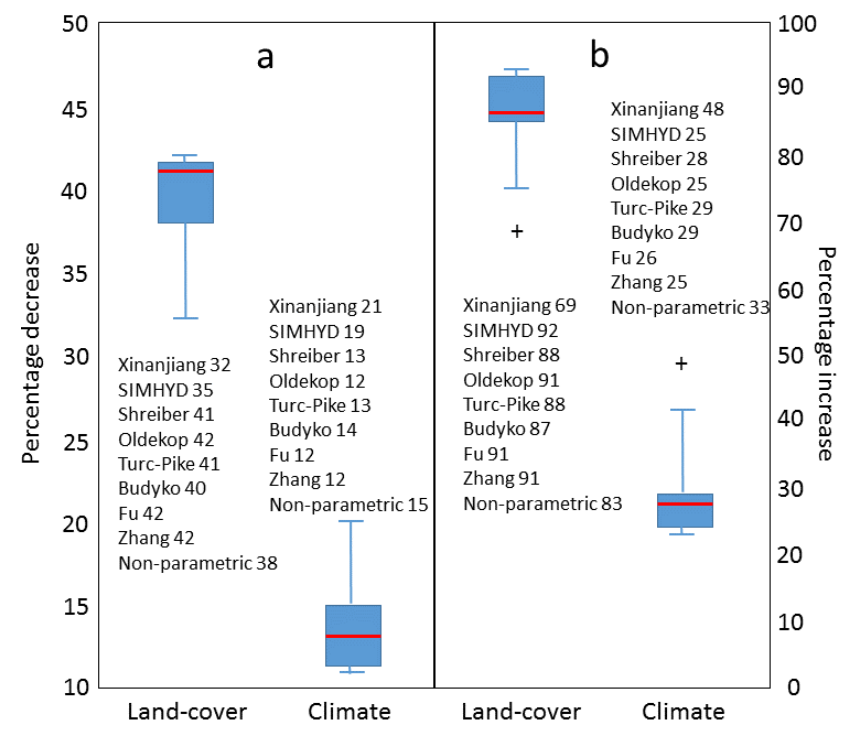

Figure 2. Percentage (a) reduction/ (b) increase in streamflow during the afforested/pre-afforestation period due to increase/decrease in plantations and drier/wetter climate estimated by the nine approaches.

ductions in streamflow due to climatic differences between the pre-afforestation and afforested periods when using the nine approaches range between 12 and $21 \%$ with a median of $13 \%$. The box and whisker plots in Fig. $2 b$ shows the percentage increase in streamflow during the pre-afforestation period due to reduction in plantations and wetter climate estimated by the nine methods. The increases in streamflow due to reduction in plantations when using the nine methods range between 69 and $92 \%$ with a median of $88 \%$. The corresponding increases in streamflow due to wetter climatic in the pre-afforestation period when using the nine methods range between 25 and $48 \%$ with a median of $28 \%$.

There is a small variability in the reduction or increase in streamflow estimated by the nine methods with the seven Budyko framework based methods providing very similar results. This is to be expected as these seven methods use the same underlying concept with little differences in the way the climate elasticity coefficients are estimated. The analysis shows that the plantation impact results from the two hydrological models are similar to those from the commonly used sensitivity-based approaches (although the Xinanjiang model results are slightly different and it underestimates the increase in streamflow due to reduction in plantations and overestimates the streamflow increase due to wetter climate when compared to the results from the other eight methods). Although very simple and easy to apply, the sensitivity-based approaches are only applicable where long term datasets are available and they only provide results at a mean annual time scale. The hydrological models simulate daily time series of plantation impacted flows and so they are suitable for estimating the relative contributions of land cover changes and

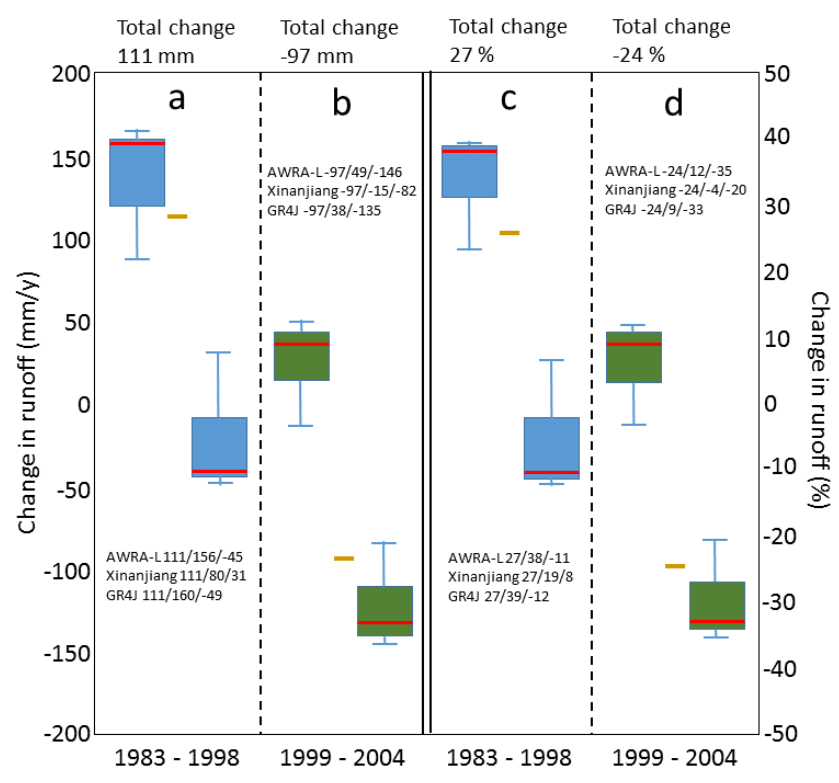

Figure 3. Summary of bushfire impact on annual streamflow from the year 1983 to 2004 in mm (two left panels $\mathbf{a}$ and $\mathbf{b}$ ) and percentage (two right panels $\mathbf{c}$ and $\mathbf{d}$ ) for the salvation Creek catchment. Blue boxplots are bushfire impact from the year 1983 to 1998, and green ones are from the year 1999 to 2004 . Within each of the four panels, the yellow dash represents total streamflow change relative to pre-bushfire period, the first boxplot represent vegetation change impact on streamflow and the second boxplot represents climate variability impact on streamflow.

climate change/variability at a daily, monthly or annual timestep. The daily time series of impacted streamflow can also be used to investigate the impacts of plantation expansion or reduction and climate change/variability on different runoff characteristics.

\subsection{Deforestation/bushfire case study}

The Starvation Creek catchment is about $31 \mathrm{~km}^{2}$ and located in the Central Highlands of Victoria, east of Melbourne. The climate is temperate, with cool and wet winters and mild to warm and dry summers. The streamflow and climate records for this catchment cover the period of 1973 to 2004. Mean annual rainfall and mean annual areal potential evapotranspiration (APET) is 1644, 1604, 1400 and 1091, 1073, $1079 \mathrm{~mm}$ for 1973-1982, 1983-1998 and 1999-2004 respectively. The vegetation cover is a mix of pure E. regnans (mountain ash) and mixed damp eucalypt species, predominantly E. obliqua, E. cypellocarpa and E. sieberi with about $51 \%$ of ash. The ash stands were all regrowth originating from the 1939 wildfires. The catchment was severely burnt during the Ash Wednesday bushfires which occurred in February 1983. The area burnt for Starvation Creek was $84 \%$, but as only $3 \%$ results in a fire-kill of ash it appears the severity was not high in this catchment. 
This study investigated the impacts of the Ash Wednesday bushfires and climate variability on streamflow in the Starvation Creek catchment using observed data and the dynamic hydrological modelling approach described above (Sect. 2.4) using three hydrological models (AWRA-L (Vaze et al., 2013); Xinanjiang (Zhao et al., 1980); GR4J (Perrin et al., 2003)). The boxplots in Fig. 3 summarise the impacts of the 1983 bushfires on annual streamflow from the year 1983 to 1998 (first 15 years post-bushfire, blue boxplots) and 1999 to 2004 (after 15 years post-bushfire, green boxplots) in mm change (two left panels a and $b$ ) and percentage change (two right panels $\mathrm{c}$ and d) for the salvation Creek catchment. The box represent the variability between the 75 th and 25 th percentile and the red line represent the median value. Within each of the four panels, the yellow/orange dash represent total streamflow change in the post-bushfire period relative to pre-bushfire period, the first boxplot represent vegetation change impact on streamflow and the second boxplot represent climate variability impact on streamflow.

The results for the first 15 years post-bushfire show that the total increase in streamflow (when compared to the prebushfire period) due to the 1983 bushfires and climate variability for the Starvation Creek catchment is $111 \mathrm{~mm}$ which represent about $27 \%$ increase in streamflow. The increase in streamflow during the first 15 years post-bushfire due to vegetation dynamics is $156 \mathrm{~mm}$ (38\% of the pre-bushfire streamflow) for the AWRA-L model, $80 \mathrm{~mm}$ (19\% of the pre-bushfire streamflow) for Xinanjiang model and $160 \mathrm{~mm}$ (39\% of the pre-bushfire streamflow) for the GR4J model. The corresponding change in streamflow due to climatic differences between the pre-bushfire and first 15 years of postbushfire period for the catchment is $-45 \mathrm{~mm}(-11 \%$ of the pre-bushfire streamflow) for the AWRA-L model, $31 \mathrm{~mm}$ ( $8 \%$ of the pre-bushfire streamflow)) for the Xinanjiang model and $-49 \mathrm{~mm}(-12 \%$ of the pre-bushfire streamflow) for the GR4J model.

The results for the period post 1998 (after 15 years postbushfire) show that the total change in streamflow (when compared to the pre-bushfire period) due to the 1983 bushfires and climate variability for the Starvation Creek catchment is $-97 \mathrm{~mm}$ which represent about $24 \%$ reduction in streamflow. The change in streamflow for the period post 1998 due to vegetation dynamics is $49 \mathrm{~mm}$ (12\% of the pre-bushfire streamflow) for the AWRA-L model, $-15 \mathrm{~mm}$ ( $-4 \%$ of the pre-bushfire streamflow) for the Xinanjiang model and $38 \mathrm{~mm}$ (9\% of the pre-bushfire streamflow) for the GR4J model. The corresponding change in streamflow due to climatic differences between the pre-bushfire and after 15 years post-bushfire period for the catchment is $-146 \mathrm{~mm}$ ( $-35 \%$ of the pre-bushfire streamflow) for AWRA-L model, $-82 \mathrm{~mm}(-20 \%$ of the pre-bushfire streamflow) for the Xinanjiang model and $-135 \mathrm{~mm}(-33 \%$ of the pre-bushfire streamflow) for the GR4J model.

The change in streamflow in the first 15 years after 1983 bushfires attributed to vegetation change when using the three models range between 80 and $160 \mathrm{~mm}$ with a median of $156 \mathrm{~mm}$ (19 and $39 \%$ with a median of $38 \%$ ). The corresponding change in streamflow due to the difference in climate between the pre-bushfire and first 15 years after the bushfire period when using the three hydrological models range between -49 and $31 \mathrm{~mm}$ with a median of $-45 \mathrm{~mm}$ ( -12 and $8 \%$ with a median of $-11 \%$ ). Post 1998 , the change in streamflow due to vegetation range between -15 and $49 \mathrm{~mm}$ with a median of $38 \mathrm{~mm}$ ( -4 and $12 \%$ with a median of $9 \%$ ). The corresponding change in streamflow due to climatic variability range between -146 and $-82 \mathrm{~mm}$ with a median of $-135 \mathrm{~mm}(-35$ and $-20 \%$ with a median of $-33 \%)$.

The results from the three models show reasonable agreement with each other. In first 15 years after bushfires, vegetation dynamics show much larger impacts on streamflow than climate variability, and result in the substantial increase in streamflow. An increase in streamflow in the early years after bushfire is consistent with conceptual models of leaf area loss/ET decrease as nearly $84 \%$ of the forest cover in the catchment was burnt in the 1983 bushfires. After 15 years post-bushfire, vegetation impacts on streamflow are negligible when compared to the impacts in the first 15 years post-bushfire. During this period, there is a large reduction in streamflow due to substantial reduction in mean annual rainfall of $244 \mathrm{~mm}$ (15\%) compared to the pre-bushfire period. The differences in the results from the three models can be partially attributed to the uncertainties in hydrological model structure and parameterisation.

\section{Summary}

Most of the forested headwater catchments are an important source of water supply in many parts of the world. It is important for responsible water resource management to understand changes in streamflow caused by vegetation dynamics in these headwater forest catchments. Natural disturbances such as bushfires and anthropogenic activities like forestation, deforestation, or logging alter vegetation, evapotranspiration and soil water status, and may affect water supplies. It is necessary to accurately estimate streamflow in water supply catchments subjected to dramatic land surface changes. This paper summarised the commonly used approaches for investigating and quantifying impacts of land-cover change on water resources and provided some examples of impacts of afforestation and bushfire on water resources in southeast Australian catchments.

The case study for the Crawford River catchment which underwent substantial afforestation was undertaken using nine approaches (one non-parametric method, six Budyko framework based methods and two conceptual hydrological models). The results from the nine methods show that both plantation expansion and climatic differences can have major effects on catchment streamflow. When compared to 
the hydrological modelling results, the Budyko framework based methods overestimate the reductions in streamflow due to increase in plantations and underestimate the streamflow reductions due to drier climate. The results from the nonparametric method are similar to those from hydrological modelling. The hydrological modelling results for the Starvation Creek catchment which experienced the Ash Wednesday bushfires suggest that there was a substantial increase in streamflow in the first 15 years after the 1983 bushfires that could not be accounted for by climate effects. There is a reasonable agreement between the bushfire and climate variability impacts on streamflow results for this first post-fire period from the three hydrological models. We hypothesise the flow increase was mainly caused by the loss of leaf area and tree morality because of the bushfires and associated reduction in interception and actual evapotranspiration. These increases are in agreement with the general pattern of significant annual water yield increase following forest disturbance. After 15 years post-bushfire, vegetation impacts on streamflow are negligible when compared to the impacts in the first 15 years post-bushfire.

Acknowledgements. This work was carried out within the CSIRO Land and Water Flagship and we acknowledge useful comments from Jin Teng.

\section{References}

Budyko, M. I.: The Heat Balance of the Earth's Surface, translated from Russian by N.A. Stepanova, US Dep. of Commer., Washington, 259 pp., 1958.

Bultot, F., Dupriez, G. L., and Gellens, D.: Simulation of land use changes and impacts on the water balance - a case study for Belgium, J. Hydrol., 114, 327-348, 1990.

Dooge, J. C. I., Bruen, M., and Parmentier, B.: A simple model for estimating the sensitivity of runoff to long-term changes in precipitation without a change in vegetation, Adv. Water Resour., 23, 153-163, 1999.

Elfert, S. and Bormann, H.: Simulated impact of past and possible future land use changes on the hydrological response of the Northern German lowland "Hunte" catchment, J. Hydrol., 383, 245-255, 2010.

Hewlett, J. D., Lull, H. W., and Reinhart, K. G.: In defense of experimental watersheds, Water Resour. Res., 5, 306-316, doi:10.1029/WR005i001p00306, 1969.

Hobbins, M. T., Ramirez, J. A., and Brown, T. C.: The complementary relationship in estimation of regional evapotranspiration: an enhanced advection-aridity model, Water Resour. Res., 37, 1389-1403, 2001.

Jackson, R. B., Jobba'gy, E. G., Avissar, R., Roy, S. B., Barrett, D. J., Cook, C. W., Farley, K. A., le Maitre, D. C., McCarl, B. A., and Murray, B. C.: Trading water for carbon with biological carbon sequestration, Science, 310, 1944-1947, 2005.

Koster, R. D. and Suarez, M. J.: A simple framework for examining the interannual variability of land surface moisture fluxes, J. Climate, 12, 1911-1917, 1999.
Kuhnel, V., Dooge, J. C. I., Okane, J. P. J., and Romanowicz, R. J.: Partial analysis applied to scale problems in surface moisture fluxes, Surv. Geophys., 12, 221-247, 1991.

Lane, P. N. J., Best, A. E., Hickel, K., and Zhang, L.: The response of flow duration curves to afforestation, J. Hydrol., 310, 253-265, 2005.

Lerat, J., Andréassian, V., Perrin, C., Vaze, J., Perraud, J.-M., Ribstein, P., and Loumagne, C.: Do internal flow measurements improve the calibration of semidistributed rainfall-runoff models?, Water Resour. Res., 48, W02511, doi:10.1029/2010WR010179, 2012.

Li, H, Zhang, Y., Vaze, J., and Wang, B.: Separating effects of vegetation change and climate variability using hydrological modelling and sensitivity-based approaches, J. Hydrol., 420, 403418, doi:10.1016/j.jhydrol.2011.12.033, 2012.

Milly, P. C. D. and Dunne, K. A.: Macroscale water fluxes - 2. Water and energy supply control of their interannual variability, Water Resour. Res., 38, 24-1-24-9, doi:10.1029/2001WR000760, 2002.

Nangia, V., Mulla, D. J., and Gowda, P. H.: Precipitation changes impact stream discharge, nitrate-nitrogen loads more than agricultural management changes, J. Environ. Qual., 39, 2063-2071, 2010.

Nandakumar, N. and Mein, R. G.: Uncertainty in rainfall-runoff model simulations and the implications for predicting the hydrologic effects of land-use change, J. Hydrol., 192, 211-232, 1997.

Perrin, C., Michel, C., and Andréassian, L.: Improvement of a parsimonious model for streamflow simulation, J. Hydrol., 279, 1-76, 2003.

Sankarasubramaniam, A., Vogel, R. M., and Limburner, J. F.: Climate elasticity of streamflow in the United States, Water Resour. Res., 37, 1771-1781, 2001.

Teng, J., Chiew, F. H. S., Vaze, J., Marvanek, S., and Kirono, D. G. C.: Estimation of climate change impact on mean annual runoff across continental Australia using Budyko and $\mathrm{Fu}$ equations and hydrological models, J. Hydrometeorol., 13,10941106, doi:10.1175/jhm-d-11-097.1, 2012.

Tuteja, N. K., Vaze, J., Teng, J., and Mutendeudzi, M.: Partitioning the effects of pine plantations and climate variability on runoff from a large catchment in southeastern Australia, Water Resour. Res., 43, W08415, doi:10.1029/2006WR005016, 2007.

Van Lill, W. S., Kruger, F. J., and Van Wyk, D. B.: The effect of afforestation with Eucalyptus Grandis Hill ex Maiden and Pinus Patula Schlecht. et Cham. On streamflow from experimental catchments at Mokobulaan, Transvaal, J. Hydrol., 48, 107-118, 1980.

Vaze, J., Barnett, P., Beale, G. T. H., Dawes, W., Evans, R., Tuteja, N. K., Murphy, B., Geeves, G., and Miller, M.: Modelling the effects of landuse change on water and salt delivery from a catchment affected by dryland salinity in south-east Australia, Hydrol. Process., 18, 1613-1637, 2004.

Vaze, J., Post, D. A., Chiew, F. H. S., Perraud, J.-M., Teng, J., and Viney, N.: Conceptual rainfall-runoff model performance with different spatial rainfall inputs, J. Hydrometeorol., 12, 11001112, doi:10.1175/2011JHM1340.1, 2011.

Vaze, J., Viney, N., Stenson, M., Renzullo, L., Van Dijk, A., Dutta, D., Crosbie, R., Lerat, J., Penton, D., Vleeshouwer, J., Peeters, L., Teng, J., Kim, S., Hughes, J., Dawes, W., Zhang, Y., Leighton, B., Perraud, J. M., Joehnk, K., Yang, A., Wang, B., Frost, A., 
Elmahdi, A., Smith, A., and Daamen, C.: The Australian Water Resource Assessment System (AWRA). Proceedings of the 20th International Congress on Modelling and Simulation (MODSIM2013), Adelaide, Australia, 1-6 December 2013.

Vertessy, R. A.: The impacts of forestry on streamflows: a review. In: Proceedings of the Second Forest Erosion Workshop, May 1999, Tech. Rep. 99/6, CRC for Catchment Hydrol., Melbourne, Australia, 1999.

Zhang, L., Dawes, W. R., and Walker, G. R.: Response of mean annual evapotranspiration to vegetation changes at catchment scale, Water Resour. Res., 37, 701-708, 2001.

Zhang, Y. Q. and Chiew, F. H. S.: Relative merits of three different methods for runoff predictions in ungauged catchments, Water Resour. Res., 45, W07412, doi:10.1029/2008WR007504, 2009.

Zhao, F. F., Zhang, L., Xu, Z. X., and Scott, D. F.: Evaluation of methods for estimating the effects of vegetation change and climate variability on streamflow, Water Resour. Res., 46, W03505, doi:10.1029/2009WR007702, 2010.
Zhao, R. J., Zhang, Y. L., Fang, L. R., Liu, X. R., and Zhang, Q. S.: The Xinanjiang model, in: Hydrological Forecasting Proceedings Oxford Symposium, IASH, 351-356, 1980.

Zheng, H. X., Zhang, L., Zhu, R. R., Liu, C. M., Sato, Y., and Fukushima, Y.: Responses of streamflow to climate and land surface change in the headwaters of the Yellow River Basin, Water Resour. Res., 45, W00A19, doi:10.1029/2007wr006665, 2009.

Zhou, Y. C., Zhang, Y. Q., Vaze, J., Lane, P., and Xu S. G.: Improving runoff estimates using remote sensing vegetation data for bushfire impacted catchments, Agr. Forest Meteorol., 182183, 332-341, doi:10.1016/j.agrformet.2013.04.018, 2013.

Zhou, Y. C., Zhang, Y. Q., Vaze, J., Lane, P., and Xu, S. G.: Impact of bushfire and climate variability on streamflow from forested catchments in southeast Australia, Hydrol. Sci. J., doi:10.1080/02626667.2014.961923, 2014. 